\title{
The association of two gall crabs (Brachyura: Cryptochiridae) with the reef-building coral Siderastrea stellata Verrill, 1868
}

\author{
R. Johnsson ${ }^{1, *}$, E. Neves ${ }^{1}$, G.M.O. Franco ${ }^{2}$ \& F.L. da Silveira ${ }^{3}$ \\ ${ }^{1}$ Instituto de Biologia, Dept. Zoologia, Universidade Federal da Bahia, Av. Adhemar de Barros s/n. Ondina, CEP: 40.170- \\ 290, Salvador BA, Brazil \\ ${ }^{2}$ Museu de Zoologia da Universidade de São Paulo, Av. Nazaré 481. Bairro do Ipiranga, CEP: 04263-000, São Paulo SP, \\ Brazil \\ ${ }^{3}$ Instituto de Biociências, Dept. Zoologia Rua do Matão, Universidade de São Paulo, trav. 14, $n^{\circ}$ 321. Cidade \\ Universitária, CEP: 05508-900, São Paulo SP, Brazil \\ (*Author for correspondence: E-mail: johnsson@ufba.br)
}

Received 3 April 2005; in revised form 4 September 2005; accepted 10 September 2005

Key words: gall crabs, Cryptochiridae, scleractinian corals, symbiotic associations, South Atlantic Ocean

\begin{abstract}
The family Cryptochiridae includes a small group of cryptic crabs that inhabit cavities in scleractinian corals. They are represented in Brazil by two species. Troglocarcinus corallicola, found from Maranhão to Bahia states and that occurs in many species of the coral families Mussidae, Faviidae, Caryophillidae and Siderastreidae. Opecarcinus hypostegus, reported from the state of Pernambuco, is mainly associated with Agaricia fragilis. The range of $O$. hypostegus is extended to Rio Grande do Norte and Alagoas states. Males are usually smaller than females, and couples may be eventually found sharing cavities. Ovigerous females and males of O. hypostegus are recorded for the first time inhabiting adjoining cavities on colonies of Siderastrea stellata, an endemic reef coral widespread along the Brazilian littoral.
\end{abstract}

\section{Introduction}

Symbiotic crabs (sensu Castro, 1976) mostly belonging to the families Trapeziidae, Tetraliidae and Cryptochiridae have been suggested as dependent on coral hosts for protection against predators, and as a food source obtained from coral products or trapped particulate material (Simon-Blecher et al., 1999; Carricart-Ganivet et al., 2004). The family Cryptochiridae includes a small group of cryptic crabs that inhabit cavities of scleractinian corals, often resulting in the development of galls. According to Carricart-Ganivet et al. (2004), 'depressions' (or pits) and 'flattened spheres' (or galls) derived from coral growth modifications are likely to be associated with the alimentary mechanisms of the crabs. Due to a striking sexual dimorphism, males are much smaller than females. Contact among mates is likely to occur during breeding periods (McCain \& Coles, 1979; Kropp \& Manning, 1987). Males are apparently short-lived (Potts, 1915), and they have been observed sharing a single gall with the cospecific female, or inhabiting the same coral host but living in adjoining cavities (Fize \& Serene, 1957; Castro, 1976; McCain \& Coles, 1979). Cryptochiridae is represented by two species in Brazil, Opecarcinus hypostegus (Shaw \& Hopkins) and Troglocarcinus carallicola Verrill, both occurring along the northeastern coast (Melo, 1996). Opecarcinus hypostegus has only been reported from the state of Pernambuco associated mainly with Agaricia fragilis Dana, an encrusting coral. Troglocarcinus carallicola has a wider distribution, 
being found from Maranhão to Bahia states including the oceanic islands of Rocas and Fernando de Noronha. Troglocarcinus corallicola also inhabits a larger number of hosts belonging to the families Mussidae, Faviidae, Caryophillidae and Siderastreidae (Kropp \& Manning, 1987).

\section{Material and methods}

Sampling was carried out on reefs in Pirangi do Norte (Rio Grande do Norte), Picãozinho and Ponta do Seixas (Paraíba), Porto de Galinhas and São José da Coroa Grande (Pernambuco) and Maragogi (Alagoas) during March 2001 (Fig. 1). At each site, about 30 colonies of S. stellata were removed with a hammer and chisel, 1-3 $\mathrm{m}$ at low tide and kept inside foam boxes while transported to the laboratory. Crabs, which were found inside dome-like holes on the surface of the coral skeletons, were removed with flexible forceps from their cavities. The material was examined under a Zeiss stereomicroscope with an eyepiece micrometer and a Nikon Coolpix 995 digital camera attached. The specimens were deposited in the Crustacea collection of the Museu de Zoologia da Universidade Federal da Bahia (UFBA).

\section{Results}

A few crabs were recorded inside the cavities of coral colonies. Most individuals were probably lost during collection and handling. Empty cavities or scars developed by newly settled gall crabs were considered as evidence of occurrence, and were observed in $10-37 \%$ of the samples in all study areas (Fig. 2).

Family CRYPTOCHIRIDAE Paulson, 1875

1. Opecarcinus Kropp \& Manning, 1987

Opecarcinus hypostegus (Shaw \& Hopkins, 1977)

Diagnosis (after Kropp \& Manning, 1987: 1014, figs 5, 6): Cornea anterolateral and terminal, occupying less than half lateral length of stalk in dorsal view. Carapace longer than wide, ornamented with numerous tubercles and some spines, smoother posteriorly. Anterolateral angle without

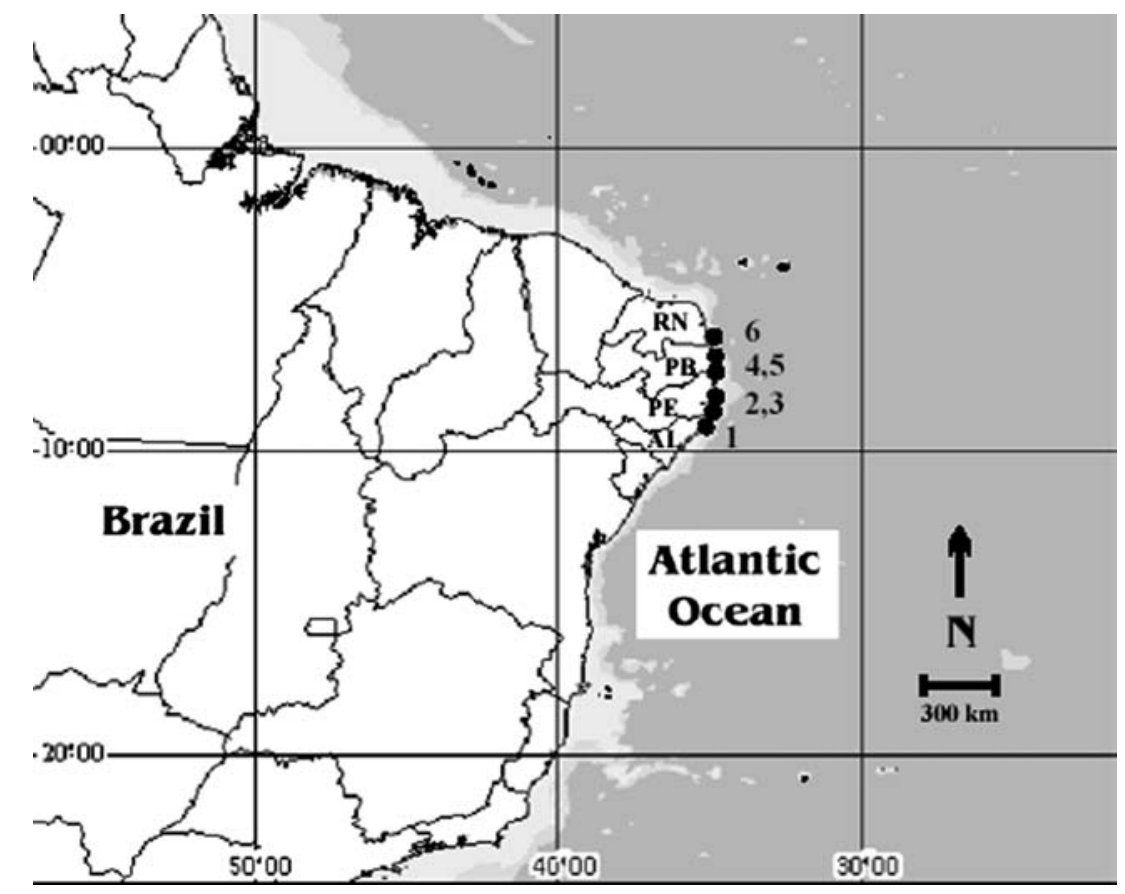

Figure 1. Map indicating sampling areas. (1) Maragogi (Alagoas State-AL), (2) São José da Coroa Grande and (3) Porto de Galinhas (Pernambuco State - PE), (4) Picãozinho and (5) Ponta do Seixas (Paraíba State - PB) and (6) Pirangi do Norte (Rio Grande do Norte State $-\mathrm{RN})$. 


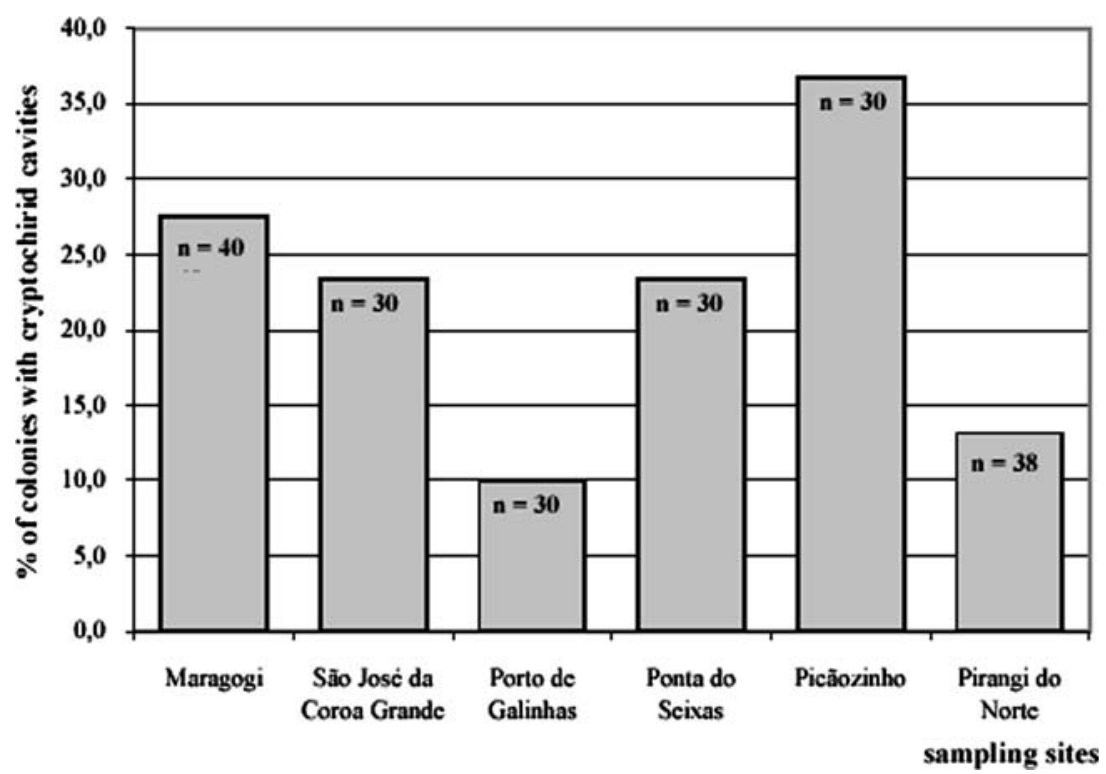

Figure 2. Percentage of colonies from each sampling area with cryptochirid cavities. $n=$ total number of colonies sampled.

prominent spine or tubercle, adjacent lateral margins with tubercles, not forming distinct border. Distal margin of antennule shorter than lateral margin.

Material examined: Two females and one male (UFBA 0008-CRU) from Pirangi do Norte (RN), two females and one male (UFBA 0009CRU), São José da Coroa Grande, and one female (UFBA 0010-CRU), Maragogi. Among the specimens examined, a heterosexual pair from Pirangi do Norte was found on the same colony of S. stellata (Fig. 3(a)-(e)).

Remarks: The specimens from northeastern Brazil have all diagnostic characters given by Kropp \& Manning (1987) to differentiate Opecarcinus from Troglocarcinus, Cedidocarcinus and Detocarcinus, the remaining Atlantic genera. Opercarcinus is characterized by (1) front deflected ventrally, (2) female pleopod 3 uniramous, (3) third maxilliped with exopod, (4) sternite of first pereopod with tubercules, and (5) pterygostomial region fused to carapace. The genus is widely distributed, being known throughout the Indo-West Pacific, Baja California in the Eastern Pacific region and the Atlantic Ocean (Kropp, 1989). However $O$. hypostegus has been recorded only from the Central Atlantic (Ascension Island), Gulf of Mexico and the Caribbean (Kropp \& Manning, 1987). Coelho (1966) reported T. corallicola on
Agaricia from Pernambuco State (Brazil). Kropp \& Manning (1987), however, refuted this identification based on the fact the species has never been found on agariciid corals, and hypothesized that Coelho (1966) was probably dealing with Opecarcinus because Agaricia is a common host. Without referring to Coelho's work, Melo (1996) confirmed the occurrence of $O$. hypostegus in Pernambuco, and considered the coral families Agaricidae and Siderastreidae as hosts. Nevertheless, the only reference to the association of Opecarcinus and Siderastrea was that of Scott (1985), who found the crab in S. siderea (Ellis \& Solander). The present results point out $S$. stellata as another host for O. hypostegus and extend its range in Brazil from Rio Grande do Norte to Alagoas states.

Ovigerous females and males of $O$. hypostegus are recorded for the first time as inhabiting adjoining cavities on colonies of Siderastrea stellata. Warner (1977) found that in Hapalocarcinus the female is fertilized before the formation of the gall, while in Cryptochirus both sexes occupy the same gall, with the male living attached to the female abdomen (Warner, 1977).

2. Troglocarcinus Verrill, 1908

Troglocarcinus corallicola Verrill, 1908 

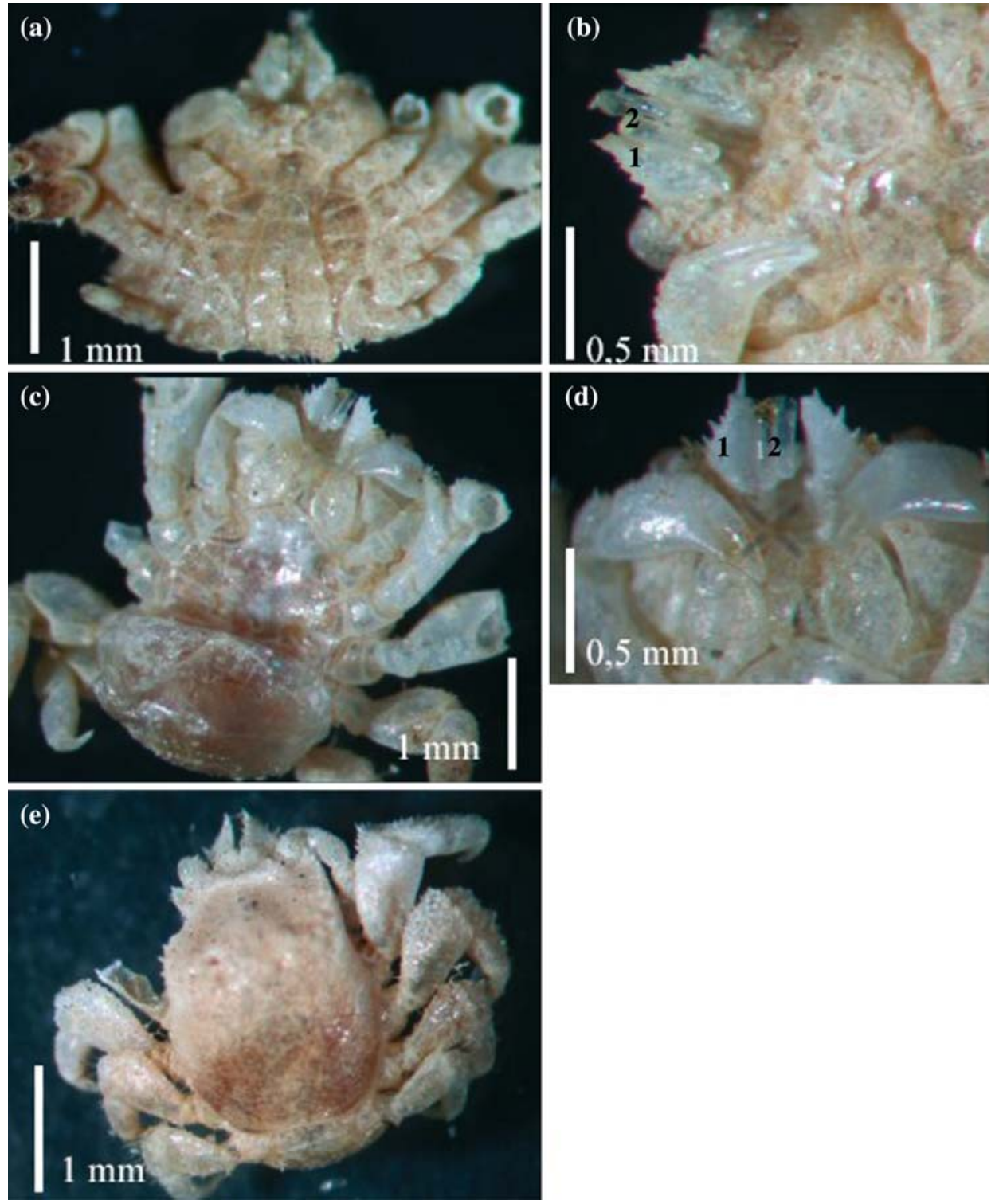

Figure 3. Opecarcinus hypostegus (UFBA 0008-CRU) found in a colony of Siderastrea stellata Verrill, 1868. (a) Male, ventral view. (b) Male, detail of mouth apparatus, antenna (1) and antennule (2). (c) Pregnant female, ventral view. (d) Female, detail of mouth apparatus, antenna (1) and antennule (2). (e) Female, dorsal view.

Diagnosis: Kropp \& Manning (1987), pages 14-18, figures 7 and 8.

Description: Cornea anterolateral, occupying more than distal half of stalk in dorsal view. Carapace longer than wide, ornamented with tubercles and some spines, posterior fourth may be smooth but pitted. Anterolateral angle with spine, and lateral margins of carapace lacking distinct border of tubercles. Basal segment of antennular peduncle with distal projection extending to or slightly beyond eyestalk.

Material examined: One female (UFBA 0011CRU) from reefs at Pirangi do Norte (RN) (Fig. 4(a) - (c)).

Remarks: Troglocarcinus and Opecarcinus share some common traits (i.e., front carapace deflected ventrally, pleopod 3 uniramous in female, third maxilliped with exopod). Several characters 

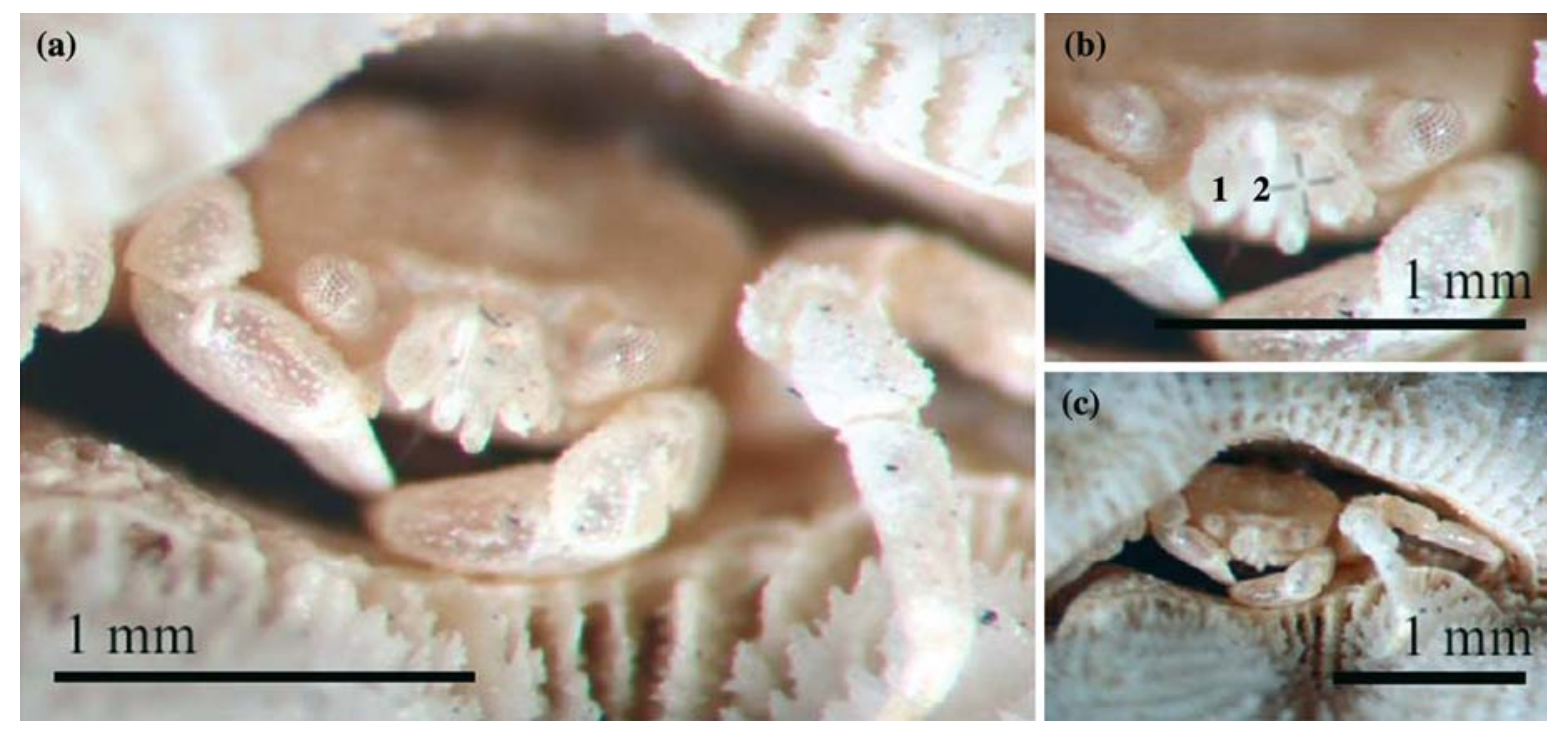

Figure 4. Troglocarcinus corallicola (UFBA 0011-CRU) found in a colony of Siderastrea stellata Verrill, 1868. (a) Female, frontal view. (b) Female, detail of cornea (1) and antenna (2). (c) Female of Troglocarcinus corallicola Verrill, 1908 inside dome-like cavity of Siderastrea stellata Verrill, 1868.

including (1) sternum of first pereopod smooth and (2) free epimeral plate, are diagnostic to Troglocarcinus. According to Kropp \& Manning (1987), besides being generalist occurring in a variety of coral hosts, $T$. corallicola is also amphiAtlantic and one of the most widely distributed cryptochirids along the Atlantic coast. Despite of the low degree of host specificity, $T$. corallicola has so far been known from a single siderastreid host, S. siderea (Kropp \& Manning, 1987).

\section{Conclusion}

The Cryptochiridae represents a unique and poorly known group of crabs, with members described from shallow tropical waters to deep water (Kropp \& Manning, 1995). The crabs have been reported in exclusive association with live scleractinian corals, depending on host mucus for feeding (Reed et al., 1982). Kropp (1986) confirmed that the structure of the mouthparts was suited for collecting mucus from their coral hosts rather than for filter feeding. The gall is lined inside with living coral tissue that produces mucus. Mucus is released into the water, thus representing a type of detrital food that may be used by other crabs (Knudsen, 1967; Preston, 1973; Castro, 1976).
Carricart-Ganivet et al. (2004), however, analyzing the stomach content of $T$. corallicola found green pigments and filamentous algae besides some foraminiferans and suspended material indicating that this species may also obtain food from material deposited in the depression (Abelson et al., 1991) Ingestion of mucus by gall crabs would not represent a metabolic drain, and so they should not be referred to as 'parasites'. In contrast, Simon-Blecher et al. (1999), working with Cryptochirus coralliodytes, emphasize the position that as the crustacean inhibits the coral growth rate and facilitates the settlement of algae and fungi, besides feeding on coral mucus, a relationship that may be a parasitic one.

Previous studies have suggested that the males of Hapalocarcinus, which show a close resemblance to the megalopa inhabit small shelters formed at the junction of growing coral branches (see Castro, 1976). Henderson (1906) observed males of Cryptochirus dimorpheus living together with females and they are rarely found free-living as stated by Edmondson (1933). Despite this observation Kropp \& Manning (1987) recorded free-living male gall crabs of $T$. corallicola. Based on the male/female ratio of this species, males move from one colony to another to mate and therefore are rarely found alone in a gall 
(Carricart-Ganivet et al., 2004). A heterosexual pair of $O$. hypostegus was nevertheless found on the same colony of $S$. stellata living inside separate, but neighboring holes.

\section{Acknowledgements}

We thank Carlos E. F. Rocha (IB-USP) for logistical support Marcos Tavares (MZ-USP) for assistance with identification Peter Castro (California State Polytechnic University) for a friendly support in stimulating the improvement of this work and Steve Coles (Bishop Museum, Hawaii) for helping with the literature. This study was supported by CNPq (no: 140170/2000-6), CAPES for granting a scholarship to the 'Pós-Graduação, Área Zoologia, IBUSP', and the Instituto de Biociências (USP)/CAPES/PROAP-2001/02.

\section{References}

Abelson, A., B. S. Galil \& Y. Loya, 1991. Skeletal modification in stony corals caused by indwelling crabs: hydrodynamical advantages for crab feeding. Symbiosis 10: 233-248.

Carricart-Ganivet, J. P., L. F. Carrera-Parra, L. I. Quan-Young \& M. S. Garcia-Madrigal, 2004. Ecological note on Troglocarcinus corallicola (Brachyura: Cryptochiridae) living in symbiosis with Mancina areaolata (Cnidaria: Scleractinia) in the Mexican Caribbean. Coral Reefs 23: 215-217.

Castro, P., 1976. Brachyuran crabs symbiotic with scleractinian corals: a review of their biology. Micronesica 121(1): 95-110.

Coelho, P. A., 1966. Alguns decápodos novos para Pernambuco e estados vizinhos na Coleção Carcinológica do Instituto Oceanográfico da Universidade Federal de Pernambuco - Segunda lista. Ciência e Cultura 18: 139-140.

Edmondson, C. H., 1933. Cryptochyrus of the Central Pacific. Bernice Bishop Museum 10(5): 1-23.

Fize, A. \& R. Serène, 1957. Les hapalocarcinidés du Viet-Nam. Memoirs du Institute Océanographique de Nhatrang 10: $1-202$.
Henderson, J. R., 1906. On a new species of coral-infesting crab taken by R.I.M.S. "Investigastor" at the Andaman Islands. Annals and Magazine of Natural History, Ser. 7 18: 2111-219.

Knudsen, J. W., 1967. Trapezia and Tetralia (Decapoda, Brachyura, Xanthidae) as obligate ectoparasites of pociloporid and acroporid corals. Pacific Science 21: 51-57.

Kropp, R. K., 1986. Feeding biology and mouthpart morphology of three species of corals gall crabs (Decapoda: Cryptochiridae). Journal of Crustacean Biology 6: 377-384.

Kropp, R. K., 1989. A revision of the Pacific species of gall crabs, genus Opecarcinus (Crustacea: Cryptochiridae). Bulletin of Marine Science 45: 98-129.

Kropp, R. K. \& R. B. Manning, 1987. The Atlantic gall crabs family Cryptochiridae (Crustacea: Decapoda: Brachyura). Smithsonian Contributions to Zoology 462: 1-21.

Kropp, R. K. \& R. B. Manning, 1995. Crustacea Decapoda: two new genera and species of deep water gall crabs from the Indo-west Pacific (Cryptochiridae). In Crosnier, A. (ed.) XV. Résultats des Campagnes MUSORSTOM. Mémoires du Muséum National d' Histoire Naturelle 168, Paris: 531-539.

McCain, J. C. \& S. L. Coles, 1979. A new species of crab (Brachyura, Hapalocarcinidae) inhabiting pocillopporid corals in Hawaii. Crustaceana 36(1): 81-89.

Melo, G. A. S., 1996. Manual de Identificação dos Brachyura (Caranguejos e Siris) do Litoral Brasileiro. Editora Plêiade, São Paulo.

Potts F. A., 1915. Hapalocarcinus, the gall forming crab, with some notes on the related Cryptochirus. Papers of the Department of Marine Biology Carnegie Institute Washington 8: 33-69.

Preston, E. M., 1973. A computer simulation of competition among five sympatric congeneric species of xanthid crabs. Ecology 54: 469-483.

Reed, J. K., R. H. Gore, L. E. Scotto \& K. A. Wilson, 1982. Community composition, structure, areal and trophic relationships of decapods associated with shallow- and deepwater Oculina varicosa reef corals. Bulletin of Marine Science 32: 761-786.

Scott P. J. B., 1985. Aspects of living coral associates in Jamaica. 5th International Coral Reef Symposium 1: 345 350.

Simon-Blecher, N., A. Chemedanov, N. Eden \& Y. Achituv, 1999. Pit structure and trophic relationship of the coral pit crab Cryptochirus coralliodytes. Marine Biology 134: 711-717.

Warner, G. F., 1977. The Biology of Crabs. Van Nostrand Reinhold Co, New York. 